\title{
PENGARUH DUKUNGAN KELUARGA TERHADAP PEMERIKSAAN PAPSMEAR PADA WANITA USIA SUBUR DI PUSKESMAS WILAYAH KABUPATEN TANGERANG
}

\author{
Dewi Puspitasari $^{1}$, Titin Martini ${ }^{2}$, Titis Wahyuni ${ }^{3}$ \\ Dosen Prodi D III Kebidanan Fakultas Ilmu Kesehatan \\ Universitas Muhammadiyah Tangerang \\ Email : dewipuspitasari138@gmail.com
}

\begin{abstract}
ABSTRAK
Masih rendahnya kesadaran Wanita Usia Subur di Indonesia melakuakan deteksi dini kanker serviks seperti papsmear maupun IVA (Infeksi Visual Asetat). Cakupan Deteksi Dini Kanker Leher Rahim Dengan Metode IVA Dan Kanker Payudara Dengan Pemeriksaan Klinis (CBE) Menurut Kecamatan Dan Puskesmas Provinsi Banten Tahun 2015 sebanyak 1,7\%.

Tujuan : Untuk mengetahui faktor-faktor yang berhubungan dengan perilaku pemeriksaan papsmear pada Wanita Usia Subur yaitu usia, pengetahuan, pendidikan, pekerjaan, biaya, tempat pelayanan dan dukungan keluarga. Penelitian ini menggunakan data primer yakni dengan menggunakan angket yang diisi oleh responden di Puskesmas Wilayah Kabupaten Tangerang. Penelitian ini bersifat deskriptif dengan metode cross sectional dengan jumlah sample 54 responden yang dipilih secara simple random sampling. Hasil yang didapatkan dari 54 responden Wanita Usia Subur yang melakukan pemeriksaan papsmear $33.3 \%$ adalah WUS dengan usia resiko, 53.8\% WUS dengan pengetahuan baik, $35.7 \%$ WUS dengan pendidikan tinggi, 33.3\% WUS yang bekerja, 43.5\% WUS yang mempunyai biaya, $42.3 \%$ WUS yang mengetahui adanya tempat pelayanan kesehatan, dan 53.8\% WUS yang mendapatkan dukungan keluarga dan melakukan pemeriksaan papsmear. Pada analisis bivariat didapatkan ada hubungan antara pengetahuan, biaya, tempat pelayanan, dan dukungan keluarga dengan perilaku pemeriksaan papsmear. Untuk selanjutnya perlu adanya pengupayaan peningkatan pengetahuan dari institusi terkait seperti puskesmas dan tenaga kesehatan setempat untuk memberikan motivasi kepada wanita terutama Wanita Usia Subur begitu pentingnya melakukan pemeriksaan papsmear.
\end{abstract}

Kata kunci : Perilaku, Papsmear, Wanita Usia Subur

\section{PENDAHULUAN}

Kanker serviks adalah kanker terbanyak ke lima pada wanita seluruh dunia dan diperkirakan terdapat $14,0 \%$ kasus baru dan 6,8\% kematian pada tahun 2012.

Faktor risiko terbanyak yang menyebabkan kematian akibat kanker berbeda pada negara-negara di dunia. faktor risiko penyebab kematian akibat kanker berbeda pada penduduk di negara berpenghasilan rendah-menengah dan negara berpenghasilan tinggi. Pada penduduk di negara berpenghasilan rendah-menengah, konsumsi alkohol, rendahnya konsumsi buah dan sayur, serta infeksi virus human papilloma $(H P V)$ menyebabkan lebih banyak kematian akibat kanker dibandingkan pada penduduk di negara berpenghasilan tinggi. Namun, merokok serta kelebihan berat badan dan obesitas merupakan faktor risiko yang lebih dominan pada 
penduduk di negara berpenghasilan tinggi.

Berdasarkan pengolahan data Riset Kesehatan Dasar (Riskesdas) tahun 2013, Badan Litbangkes Kementerian Kesehatan RI dan Data Penduduk Sasaran, Pusdatin Kementerian Kesehatan RI Penyakit kanker serviks dan payudara merupakan penyakit kanker dengan prevalensi tertinggi di Indonesia pada tahun 2013, yaitu kanker serviks sebesar $0,8 \%$ dan kanker payudara sebesar 0,5\%o.

Yayasan Kanker Indonesia (YKI) dan Perempuan Peduli Kanker Serviks (PPKS) mencatat, kasus baru kanker serviks di Indonesia mencapai 40 hingga 45 kasus per hari. Jumlah kematian karena kanker serviks mencapai 20 hingga 25 orang perhari. Setiap satu jam, seorang perempuan meninggal karena kanker serviks. Salah satu faktor penyebab semakin berkembangnya kanker serviks di Indonesia disebabkan karena rendahnya cakupan deteksi dini seperti Pap Smear maupun IVA (Inspeksi Visual Asam Asetat).

Skrining merupakan upaya deteksi dini untuk mengidentifikasi penyakit atau kelainan yang secara klinis belum jelas dengan menggunakan tes, pemeriksaan atau prosedur tertentu. Upaya ini dapat digunakan secara cepat untuk membedakan orang-orang yang kelihatannya sehat tetapi sesungguhnya menderita suatu kelainan. Skrining kanker payudara di Puskesmas Penyelenggara Deteksi Dini dilakukan dengan Clinical Breast Examination $(C B E)$ dan skrining kanker serviks dilakukan dengan tes IVA (Inspeksi Visual Asam Asetat).

\section{METODE PENELITIAN}

Penelitian ini adalah dengan desain penelitian cross sectional dengan metode kuantitatif. Sebanyak 54 responden ikut serta dalam penelitian ini. Data menggunakan data primer dengan menyebarkan kuesioner penelitian kepada responden. Pada penelitian ini variabel independen menurut kelompoknya yang akan diteliti adalah:

1) Faktor predisposisi yaitu, umur, pendidikan, pekerjaan, biaya, dan pengetahuan.

2) Faktor pemungkin meliputi, ketersediaan pelayanan kesehatan, keterjangkauan pelayanan kesehatan, dan biaya.

3) Faktor penguat adalah dorongan keluarga (suami, anak, orang tua/ mertua), dorongan teman dan keterpaparan informasi tentang kanker serviks.

Data diolah menggunakan komputer.

\section{HASIL PENELITIAN}

\section{Tabel 1}

Distribusi Frekuensi Wanita Usia Subur yang melakukan Pemeriksaan Papsmear di Puskesmas Kabupaten Tangerang

\begin{tabular}{cccc}
\hline No & Pemeriksaan Papsmear & Frekuensi & Presentase (\%) \\
\hline 1. & Melakukan Pemeriksaan Papsmear & 15 & $27,8 \%$ \\
2. & Tidak Melakukan Pemeriksaan Papsmear & 39 & $72,2 \%$ \\
& Jumlah & $\mathbf{5 4}$ & $\mathbf{1 0 0}$ \\
\hline
\end{tabular}

Hasil distribusi frekuensi data responden tentang pemeriksaan papsmear, diketahui bahwa sebanyak 15 wanita usia subur $(27,8 \%)$ melakukan pemeriksaan. papsmear dan sebanyak 
melakukan pemeriksaan papsmear.

\section{Tabel 2}

Distribusi Frekuensi Wanita Usia Subur berdasarkan Pengetahuan di Puskesmas Kabupaten Tangerang

\begin{tabular}{cccc}
\hline No & Pengetahuan & Frekuensi & Presentase (\%) \\
\hline 1. & Baik & 13 & $42,6 \%$ \\
2. & Tidak Baik & 41 & $75,9 \%$ \\
& Jumlah & $\mathbf{5 4}$ & $\mathbf{1 0 0}$ \\
\hline
\end{tabular}

Hasil distribusi frekuensi data tingkat pengetahuan yang baik dan responden tentang pemeriksaan papsmear, diketahui bahwa sebanyak 13 wanita usia subur $(42,6 \%)$ memiliki

\section{Tabel 3}

Distribusi Frekuensi Wanita Usia Subur berdasarkan Pendidikan di Puskesmas Kabupaten Tangerang

\begin{tabular}{cccc}
\hline No & Pendidikan & Frekuensi & Presentase (\%) \\
\hline 1. & Tinggi & 28 & $51,9 \%$ \\
2. & Rendah & 26 & $48,1 \%$ \\
& Jumlah & $\mathbf{5 4}$ & $\mathbf{1 0 0}$ \\
\hline
\end{tabular}

Hasil distribusi frekuensi data pendidikan tinggi dan sebanyak 26 responden tentang pemeriksaan papsmear, diketahui bahwa sebanyak 28 wanita usia subur $(48,1 \%)$ memiliki wanita usia subur $(51,9 \%)$ memiliki pendidikan rendah.

\section{Tabel 4}

Distribusi Frekuensi Wanita Usia Subur berdasarkan Dukungan Keluarga di Puskesmas Kabupaten Tangerang

\begin{tabular}{cccc}
\hline No & Dukungan Keluarga & Frekuensi & Presentase (\%) \\
\hline 1. & Mendudukung & 12 & $22,2 \%$ \\
2. & Tidak Mendukung & 42 & $77,8 \%$ \\
& Jumlah & $\mathbf{5 4}$ & $\mathbf{1 0 0}$ \\
\hline
\end{tabular}

Hasil distribusi frekuensi data responden tentang pemeriksaan papsmear, diketahui bahwa sebanyak 12 wanita usia subur $(22,2 \%)$ mendapat dukungan dari keluarga dan sebanyak 42 wanita usia subur $(77,8 \%)$ tidak mendapat dukungan dari keluarga. 
Tabel 5

Hubungan Pengetahuan Wanita Usia Subur dengan Pemeriksaan Papsmear di Puskesmas Kabupaten Tangerang

\begin{tabular}{ccccccccc}
\hline \multirow{2}{*}{ Pengetahuan } & \multicolumn{2}{c}{ Pemeriksaan Papsmear } & \multicolumn{2}{c}{ Total } & OR & P Value \\
& \multicolumn{2}{c}{ Tidak } & \multicolumn{2}{c}{ Ya } & & & (95\% CI) & \\
\hline Tidak Baik & 33 & 80.5 & 8 & 19.5 & 41 & 100 & 4,813 & 0,040 \\
Baik & 6 & 46.2 & 7 & 53.8 & 13 & 100 & $1,265-18,311$ & \\
Jumlah & $\mathbf{3 9}$ & $\mathbf{9 2 . 6}$ & $\mathbf{1 5}$ & $\mathbf{2 7 . 8}$ & $\mathbf{5 4}$ & $\mathbf{1 0 0}$ & & \\
\hline
\end{tabular}

Hasil analisis hubungan pendidikan dengan perilaku pemeriksaan papsmear diperoleh bahwa ada sebanyak 7 (53.8\%) Wanita Usia Subur dengan pengetahuan baik melakukan pemeriksaan papsmear, sedangkan diantara Wanita Usia Subur dengan pengetahuan tidak baik 8 (19.5\%), melakukan pemeriksaan papsmear. Hasil uji statistik diperoleh nilai $\mathrm{P}$ Value $=0.040$ maka dapat disimpulkan ada perbedaan proporsi pengetahuan baik dan tidak baik dengan perilaku pemeriksaan papsmear (ada hubungan yang signifikan antara pengetahuan dengan perilaku pemeriksaan papsmear). Dari hasil analisis diperoleh nilai $\mathrm{OR}=4.813$ artinya Wanita Usia Subur dengan pengetahuan baik mempunyai peluang 4.813 kali melakukan pemeriksaan papsmear.

\section{Tabel 6}

Hubungan Pendidikan Wanita Usia Subur dengan Pemeriksaan Papsmear di Puskesmas Kabupaten Tangerang

\begin{tabular}{|c|c|c|c|c|c|c|c|c|}
\hline \multirow[t]{3}{*}{ Pendidikan } & \multicolumn{4}{|c|}{ Pemeriksaan Papsmear } & \multicolumn{2}{|c|}{ Total } & \multirow{3}{*}{$\begin{array}{c}\text { OR } \\
(95 \% \mathrm{CI})\end{array}$} & \multirow[t]{3}{*}{ P Value } \\
\hline & \multicolumn{2}{|c|}{ Tidak } & \multicolumn{2}{|c|}{ Ya } & & & & \\
\hline & $\mathbf{F}$ & $\%$ & $\mathbf{F}$ & $\%$ & $\mathbf{F}$ & $\%$ & & \\
\hline Rendah & 21 & 80.8 & 5 & 19.2 & 26 & 100 & 2.333 & 0.295 \\
\hline Tinggi & 18 & 64.3 & 10 & 35.7 & 28 & 100 & $0.672-8.099$ & \\
\hline Jumlah & 39 & 72.2 & 15 & 27.8 & 54 & 100 & & \\
\hline
\end{tabular}

Hasil analisis hubungan pendidikan dengan perilaku pemeriksaan papsmear diperoleh bahwa ada sebanyak 10 (35.7\%) Wanita Usia Subur yang berpendidikan tinggi melakukan deteksi dini kanker serviks, sedangkan diantara Wanita Usia Subur yang berpendidikan rendah ada 5 $(19.2 \%)$ yang melakukan pemeriksaan papsmear. Hasil uji statistik diperoleh nilai $\mathrm{P}$ Value $=0.295$ maka dapat disimpulkan tidak ada perbedaan proporsi Wanita Usia
Subur yang berpendidikan tinggi dan Wanita Usia Subur yang berpendidikan rendah dengan perilaku pemeriksaan papsmear. Tidak ada hubungan yang signifikan antara pendidikan dengan perilaku pemeriksaan papsmear . Dari hasil analisis diperoleh nilai $\mathrm{OR}=2.333$ artinya Wanita Usia Subur yang berpendidikan tinggi mempunyai peluang 2.333 kali melakukan pemeriksaan papsmear. 
Tabel 7

Hubungan Dukungan Wanita Usia Subur dengan Pemeriksaan Papsmear di
Puskesmas Kabupaten Tangerang

\begin{tabular}{ccccccccc}
\hline & \multicolumn{3}{c}{ Pemeriksaan Papsmear } & \multicolumn{2}{c}{ Total } & \multicolumn{2}{c}{ OR (95\% CI) } & \\
Dukungan Keluarga & \multicolumn{2}{c}{ Tidak } & \multicolumn{2}{c}{ Ya } & & & \\
& F & \% & F & \% & $\sum$ & \% & & \\
\hline Tidak Mendukung & 34 & 81.0 & 8 & 19.0 & 42 & 100 & $5.950(1.492-23.701)$ \\
Mendukung & 5 & 41.7 & 7 & 58.3 & 12 & 100 & & 0.021 \\
Jumlah & 39 & 72.3 & 15 & 21.7 & 54 & 100 & & \\
\hline
\end{tabular}

Hasil analisis hubungan dukungan keluarga dengan perilaku pemeriksaan papsmear diperoleh bahwa ada sebanyak 7 $(58.3 \%)$ Wanita Usia Subur yang mendapat dukungan keluarga melakukan pemeriksaan papsmear, sedangkan diantara Wanita Usia Subur yang tidak mendapat dukungan keluarga, ada $8 \quad(19.0 \%)$ melakukan pemeriksaan papsmear. Hasil uji statistik diperoleh nilai $\mathrm{P}$ Value $=0.021$

\section{PEMBAHASAN}

\section{Pengetahuan}

Berdasarkan hasil penelitian ini didapatkan bahwa Wanita Usia Subur $53.8 \%$ berpengetahuan baik dan melakukan pemeriksaan papsmear, sedangkan Wanita Usia Subur yang berpengetahuan rendah dan telah melakukan pemeriksaan papsmear sebesar $19.5 \%$. Hal ini berarti bahwa tingkat pengetahuan Wanita Usia Subur tentang pemeriksaan papsmear di KabupatenTangerang cukup tinggi. Peningkatan pengetahuan tidak selalu menyebabkan perubahan perilaku, namun hubungan positif. Pengetahuan tertentu tentang kesehatan. Mungkin penting sebelum suatu tindakan kesehatan dilakukan tetapi tindakan kesehatan yang diharapkan mungkin tidak akan terjadi kecuali apabila seseorang mendapat isyarat yang cukup kuat untuk memotivasinya bertindak atas dasar pengetahuan yang dimilikinya. maka dapat disimpulkan ada perbedaan proporsi dukungan keluarga dengan pemeriksaan papsmear (ada hubungan yang signifikan antara dukungan keluarga dengan perilaku pemeriksaan papsmear). Dari hasil analisis diperoleh nilai OR = 5.950 artinya Wanita Usia Subur yang memperoleh dukungan dari keluarga mempunyai peluang 5.950 kali melakukan pemeriksaan papsmear.

Hal ini sesuai dengan hasil penelitian Hasbiah di Palembang (2002), dari 78 responden yang diteliti menunjukkan adanya hubungan pengetahuan dengan perilaku pemeriksaan papsmear.

Pengetahuan adalah merupakan hasil dari tahu dan ini terjadi setelah orang melakukan pengindraan terhadap obyek tertentu. Penginderaan terhadap obyek terjadi melalui panca indra manusia, yakni: penglihatan, pendengaran, penciuman, rasa, dan raba. Sebagian besar pengetahuan manusia diperoleh melalui mata dan telinga (Notoatmodjo, 2003).

Pengetahuan umumnya datang dari pengindraan yang terjadi melalui panca indra manusia, yakni : indra penglihatan, pendengaran, penciuman, rasa dan raba. Sebagian besar pengetahuan manusia diperoleh melalui mata dan telinga. Pengetahuan dan gontitif merupakan domain yang sangat penting untuk terbentuknya tindakan seseorang ( Notoamodjo, 2003 ). Pengetahuan pada dasarnya terdiri dari sejumlah fakta dan 
teori yang memungkinkan seseorang untuk dapat memecahkan masalah yang dihadapinya, pengetahuan diperoleh baik dari pengalaman langsung maupun pengalaman orang lain ( Notoatmodjo, 2003 ). Menurut Bloom dalam Notoatmodjo (2007) pengetahuan yang tercakup dalam domain kognitive mempunyai 6 tingkatan yaitu Tahu (know), Memahami (Comprehension), Aplikasi (Application), Analisis (Analysis), Sintesis (syntesis), Evaluasi (Evaluation).

\section{Pendidikan}

Hasil analisis hubungan pendidikan dengan perilaku pemeriksaan papsmear diperoleh bahwa sebanyak $35.7 \%$ ibu dengan pendidikan tinggi melakukan pemeriksaan papsmear, sedangkan ibu dengan pendidikan rendah $19.2 \%$ yang melakukan pemeriksaan papsmear. Hasil penelitian ini menunjukan bahwa semakin tinggi tingkat pendidikan Wanita Usia Subur akan semakin besar kepedulian Wanita Usia Subur untuk melakukan pemeriksaan papsmear.

Semakin tinggi tingkat pendidikan, semakin besar kepedulian terhadap kesehatan. Dengan pendidikan yang baik memberikan pada wanita kekuasaan dan kepercayaan diri untuk mengambil tanggun jawab atas wanita itu sendiri (Soemanto, 2003). Koentjoroningrat (2001), mengatakan pendidikan adalah kemahiran menyerap pengetahuan akan meningkat sesuai dengan seseorang dan kemampuan ini berhubungan erat dengan sikap seseorang terhadap pengetahuan yang diserapnya. Semakin tinggi tingkat pendidikan semakin mudah untuk dapat menyerap pengetahuan.

Pendidikan adalah usaha sadar dan terencana untuk mewujudkan suasana belajar dan proses pembelajaran agar peserta didik secara aktif aktif mengembangankan potensi dirinya untuk memiliki kekuatan spiritual keagamaan, pengendalian diri, kepribadian, kecerdasan, akhlak mulia, serta keterampilan yang diperlukan dirinya dan masyarakat (UU SISDIKNAS no. 20 tahun 2003).

\section{Dukungan Keluarga}

Dari hasil penelitian didapatkan hasil analisis crosstab hubungan dukungan keluarga dengan praktek deteksi dini kanker serviks diperoleh $58.3 \%$ Wanita Usia Subur yang mendapatkan dukungan keluarga dan melakukan pemeriksaan papsmear, sedangkan Wanita Usia Subur yang tidak mendapatkan dukungan keluarga dan melakukan pemeriksaan papsmear sebanyak $19.0 \%$ Wanita Usia Subur. Setelah diadakan uji statistic bivariat didapatkan hasil Ha ditolak artinya ada hubungan antara dukungan keluarga dengan pemeriksaan papsmear.

Hasil penelitian ini menunjukan bahwa Wanita Usia Subur yang mendapatkan dukungan keluarga cenderung melakukan pemeriksaan papsmear dibanding Wanita Usia Subur yang tidak mendapatkan dukungan keluarga.

Hal ini sesuai dengan teori Notoatmodjo (2003) mengatakan bahwa perilaku orang banyak dipengaruhi oleh seseorang penting, maka apa yang dikatakan dan dilakukannya cendrung untuk di ikuti atau didengar. Demikian juga halnya untuk merubah perilaku seseorang terhadap pemeriksaan deteksi dini kanker serviks sangatlah dibutuhkan pengaruh atau dukungan dari orang-orang yang dianggap penting dalam kehidupannya.

Notoatmodjo (2005) bahwa dengan memberikan informasi secara langsung tentang kebiasaan hidup sehat dan cara pencegahan penyakit diharapkan akan terjadi peningkatan pengetahuan sikap dan perilaku kesehatan dalam diri individu / kelompok sasaran yang berdasarkan kesadaran dan kemauan individu yang bersangkutan.

Harapan dari penelitian ini adalah meningkatkan kesadaran bagi Wanita Usia Subur tentang pentingnya untuk melakukan praktek deteksi dini kanker serviks sehingga dapat menurunkan 
prevalensi angka kejadian kanker pada Wanita Usia Subur.

\section{KESIMPULAN}

Hasil penelitian bahwa dari 54 Wanita Usia Subur yang telah melakukan pemeriksaan papsmear masih sangat sedikit yaitu sebesar 27.8\%. Dari 54 Wanita Usia Subur terdapat 53,8\% yang memiliki pengetahuan baik, dan $19.5 \%$ tidak memiliki pengetahuan baik. Dari 54 Wanita Usia Subur terdapat 35.7\% berpendidikan tinggi, dan $19.2 \%$ berpendidikan rendah. Dari 54 responden Wanita Usia Subur yang melakukan pemeriksaan papsmear terdapat $58.3 \%$ yang mendapatkan dukungan keluarga, dan $19.0 \%$ tidak mendapatkan dukungan keluarga. Hasil penelitian ini terdapat hubungan yang bermakna antara pengetahuan Wanita Usia Subur dan dukungan keluarga dengan perilaku pemeriksaan papsmear.

\section{PUSTAKA}

Arif, dkk, 2000. Kapita Selekta Kedokteran edisi ketiga. Jakarta, Media

Aesculapius.

Aziz MF, 2000Skrining dan Deteksi dini Kanker Servik, Fakultas Kedokteran Universitas Indonesia Jakarta 1995 in: Ramli.HM,et al eds. Deteksi dini Kanker, Jakrta Balai Punerbit FKUI, 97-110

Bakar A, $\quad$ http://www.mediaindonesia.comberitalasp. Alliance for Cervical Cancer Prevention (ACCP), 2002. Cervical Cancer Prevention Fact Sheet. Diunduh tanggal 24 April 2018

Buletin Jendela, 2015. Situasi Penyakit Kanker. Pusat Data dan Informasi Kementerian Kesehatan RI.

Depkes RI, 2005. Penanggulangan Kanker Serviks, Depkes. RI.

Leher Rahim dan Kanker
Payudara, Direktorat
Pengendalian Penyakit Tidak
menular Direktorat Jenderal PP
\& PL.
faktor risiko penyakit kanker.
Depkes RI
Penatalaksanaan Penyakit
Kanker Tertentu di Komunitas.
Depkes.RI.

FKUI,1998. Manual Pra Kanker dan Kanker Servik Uterus, Bagian Obstefri Genekologi

1998 Protokol Kanker Sprviks, Sub Bagian Onkologi Bagian Obstetri Genekologi FKUI.

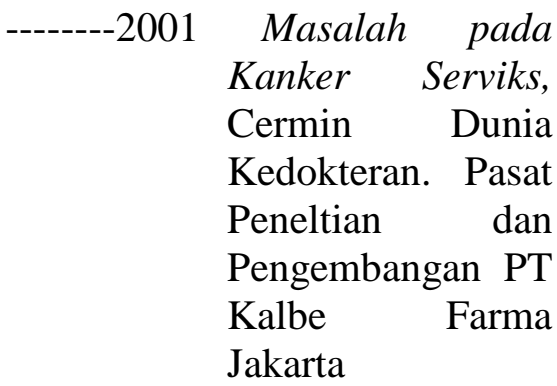

Green. W.L.at al, 1980. Health Educational Planning A.Diagnostik Approact, May Field Publishing Company.

Manuaba, I.B.G,1998. Memahami

Kesehatan Reproduksi Wanita. Jakarta,

Arcan.

Manauba, I.B.G. 2005. Pemeriksaan Pap Smear, dalam Rusmini \& Sari.l.eds.Dasar-dasar Tehnik 
Operasi

Jakarta,EGC.100-104.

Notoatmodjo,S.1999. Pengantar

Pendidikan Kesehatan dan Praktek

Kesehatan, Andi Offis Yogyakarta

-------- 2002. Metodologi dan Penelitian

Kesehatan, Rineka Cipata, Jakarta

2003. Pendidikan dan Praktek

Kesehatan, Rineka Cipta, Jakarta
2005.Promosi Kesehatan Teori dan

aplikasi, Rineka Cipta Jakarta

Yayasan kanker Indonesia, 1993. Informasi Dasar Tentang Kanker, Pedoman Bagi Penyuluh Kanker, Yayasan Kanker Indonesia Bekerja Sama dengan program for Appropriate Tehnology in Health (path)

Widyastuti Yani. Dkk. 2009 kesehatan reproduksi. Penerbit Fitramaya. 